\title{
СОЦАЛЬНИЙ РОЗВИТОК
}

https://doi.org/10.15407/dse2019.04.071

УДК 330.59(477)

JEL CLASSIFICATION: J88

\section{В.П. АНТОНЮК}

д-р екон. наук, проф., голов. наук. співроб.

Інститут економіки промисловості НАН України

03057, Україна, м. Київ, вул. Марії Капніст, 2

E-mail: antonukvp@gmail.com

ORCID 0000-0003-2100-7343

\section{Л.В. ЩЕТІНІНА}

канд. екон. наук, доц., старш. наук. співроб.

Інститут економіки промисловості НАН України

03057, Україна, м. Київ, вул. Марії Капніст, 2

E-mail: sludval@ukr.net

ORCID 0000-0003-1519-0647

\section{ОЦІНКА І ПРІОРИТЕТИ ДОБРОБУТУ НАСЕЛЕННЯ УКРАЇНИ}

На основі статистичної інформації здійснено аналіз основних параметрів рівня добробуту населення в Україні за остання п'ять років. Охарактеризовано особливості аналізу добробуту населення Украӥни, які полягають у відсутності повної достовірної інформації щодо доходів населення. На основі аналізу низки показників доведено, що найбільше зниження рівня добробуту населення відбулося в 2014 i 2015 роках, у 2017 році були досягнуті певні позитивні зрушення. Метою статті є виявлення найгостріших проблем у забезпеченні гідного рівня життя українського населення та розробка адекватних напрямів соціальної політики у сфері підвищення його добробуту. Вагомими результатами дослідження є такі: установлено головні тенденції зміни показників добробуту населення, зокрема: відновлено зростання реальних доходів населення, але їх обсяг не відновився до рівня 2013 року; динамічно зростає заробітна плата, однак зростає також заборгованість із заробітної плати; зростають пенсії, але менше за зростання заробітної плати, не відбулося суттєвого зменшення заощаджень на депозитах домашніх господарств, зростає роздрібний товарооборот та попит на послуги. Виконано аналіз стану добробуту населення за показниками частки витрат домогосподарств, які спрямовуються на продовольчі товари; частки працівників, у яких заробітна плата є низькою; частки населення з доходами нижче від фактичного прожиткового мінімуму. Зроблено висновок, що, не зважаючи на складне економічне становище, соціальну політику уряду можна характеризувати як задовільну, оскільки вдалося переломити негативну тенденцію та досягти певних успіхів у подоланні бідності. На основі макроекономічних показників здійснено оцінку соціально-економічної політики, яка свідчить про позитивні зрушення в динаміці факторних доходів населення, однак вказує на звуження соціальної спрямованості державного бюджету. Усфері добробуту українців є багато невирімених проблем, для подолання яких обгрунтовано пріоритетні завдання соціально-економічної політики в контексті Цілей сталого розвитку. Встановлено, що неоднозначність оцінювання процесів у матеріальному становищі населення спричинена відсутністю повної інформації за статистичними даними, даними обстеження домогосподарств; відсутністю інформації про тіньові доходи. Оцінено соціально-економічну політику в Україні за роз- 
робленою авторами причинно-наслідковою моделлю. Розроблено та обгрунтовано напрями соціальної політики у сфері підвищення добробуту населення.

Ключові слова: соціальна політика, рівень життя населення, добробут населення, матеріальне становище населення.

\section{V.P. Antoniuk}

Doctor of Economics, prof., Chief Researcher

Institute of Industrial Economics of the National Academy of Sciences of Ukraine

03057, Ukraine, Kyiv, st. Mary Kapnist, 2

E-mail: antonukvp@gmail.com

ORCID 0000-0003-2100-7343

\section{L.V. Shchetinina}

$\mathrm{PhD}$ (Economics), associate professor, Senior Researcher

Institute of Industrial Economics of the National Academy of Sciences of Ukraine

03057, Ukraine, Kyiv, st. Mary Kapnist, 2

E-mail: sludval@ukr.net

ORCID 0000-0003-1519-0647

\section{ASSESSMENT AND PRIORITIES OF WELFARE OF THE POPULATION OF UKRAINE}

An analysis of the basic parameters of living standards in Ukraine in the last five years is carried out in the article on the basis of statistical information. The peculiarities of analysis of the welfare of the population of Ukraine, consisting of the absence of complete reliable information on incomes of the population, are characterized. Based on the analysis of a number of indicators, it is proved that the greatest decline in living standards occurred in 2014 and 2015, with some positive changes in 2017. The purpose of the article is to identify the most acute problems in the living standards of the Ukrainian population and to develop adequate social policy directions in the field of improving its welfare. The most significant results of the study are the following: the main tendencies of changes in the indicators of the living standard of the population are established, in particular: the growth of real incomes has been restored, but their volume has not recovered to the level of 2013; wages are growing dynamically, but wage arrears are also increasing; pensions are rising, but to a lesser extent than wages; there has not been a significant reduction in savings on household deposits; retail sales and demand for services are increasing. The analysis of the living standard of the population is carried out on the indicators of the share of expenses of households, which are directed to foodstuffs; the proportion of workers who have low wages; the share of the population with incomes below the actual living wage. It is concluded that, despite the difficult economic situation, the government social policy can be characterized as satisfactory, because it reversed the negative trend and achieved some success in overcoming poverty. On the basis of macroeconomic indicators, an assessment of socioeconomic policy is made, which indicates positive changes in the dynamics of factor incomes, but indicates a narrowing of the social orientation of the state budget. There are many unresolved issues in the welfare of Ukrainians, for which the priority tasks of socio-economic policy in the context of the goals of sustainable development are substantiated. It is established that ambiguity of assessment processes in the financial situation of the population is caused by the lack of complete information on the statistical data, household survey data; lack of information about shadow revenues. The socio-economic policy in Ukraine is estimated by the author's causative and consequential model. The directions of social policy in the field of increasing the population wellbeing are developed and substantiated.

Keywords: social policy, population living standard, population welfare, financial situation of the population.

\section{В.П. Антонюк}

Д-р экон. наук, проф., глав. науч. сотр.

Институт экономики промышленности НАН Украины

03057, Украина, г. Киев, ул. Марии Капнист, 2

E-mail: antonukvp@gmail.com

ORCID 0000-0003-2100-7343 


\section{Л.В. Щетинина}

канд. экон. наук, доц., старш. науч. сотр.

Институт экономики промышленности НАН Украины

03057, Украина, г. Киев, ул. Марии Капнист, 2

E-mail: sludval@ukr.net

ORCID 0000-0003-1519-0647

\section{ОЦЕНКА И ПРИОРИТЕТЫ БЛАГОСОСТОЯНИЯ НАСЕЛЕНИЯ УКРАИНЫ}

На основе статистической информации осуществлен анализ основных параметров благосостояния населения в Украине за последнее пять лет. Охарактеризованы особенности анализа благосостояния населения Украины, состоящие в отсутствии полной достоверной информации о доходах населения. На основе анализа ряда показателей доказано, что наибольшее снижение уровня благосостояния произошло в 2014 и 2015 годах, в 2017 году были достигнуты определенные положительные сдвиги. Цель статьи - выявление наиболее острых проблем в обеспечении необходимого уровня жкизни украинского населения и разработка адекватных направлений социальной политики в сфере повышения его благосостояния. Значимые результаты исследования таковы: восстановлен рост реальных доходов населения, но их оббем не восстановился до уровня 2013 года; динамично растет заработная плата, однако растет также задолженность по заработной плате; растут пенсии, но в меньшей степени, чем размер заработной платы, не произошло существенного уменьшения сбережений на депозитах домашних хозяйств, растет розничный товарооборот и спрос на услуги. Выполнен анализ уровня жизни населения по показателям доли расходов домохозяйств, направляемых на продовольственные товары; доли работников, у которых заработная плата низкая; доли населения с доходами ниже фактического прожиточного минимума. Сделан вывод, что, несмотря на сложное экономическое положение, социальную политику правительства можно охарактеризовать как удовлетворительную, поскольку удалось переломить негативную тенденцию и достичь определенных успехов в преодолении бедности. На основе макроэкономических показателей осуществлена оценка социально-экономической политики, которая свидетельствует о позитивных сдвигах в динамике факторных доходов, однако наблюдается сужение социальной направленности государственного бюджета. В сфере благосостояния украинцев есть много нерешенных проблем, для преодоления которых обоснованы приоритетные задания социально-экономической политики в контексте Целей устойчивого развития. Установлено, что неоднозначность оценки процессов в материальном положении населения вызвана отсутствием полной информации о статистических данных, данных обследования домохозяйств; отсутствием информации о теневых доходах. Социально-экономическая политика в Украине оценена согласно разработанной авторами причинно-следственной модели. Разработаны и обоснованы направления социальной политики в сфере повышения благосостояния населения.

Ключевые слова: социальная политика, уровень жизни населения, благосостояние населения, материальное положение населения.

Постановка проблеми та актуальність. Науковці та практики, як правило, оцінюють соціальну політику в країні дуже узагальнено, без належної оцінки панівних тенденцій та / або проблем у соціальній сфері. Крім того, заклики приділяти більше уваги соціальним питанням дуже часто є популістськими і не підкріплені економічними можливостями країни, тобто станом іiі економіки. Тому автори статті вважають, що необхідно оцінити стан добробуту українського населення та обгрунтувати напрями соціальної політики для його покращення.

Під поняттям «добробут населення» автори розуміють забезпеченість населення необхідними для життя матеріальними та духовними благами. Матеріальний добробут українського населення, якщо порівнювати його з показниками інших країн, на думку авторів, є одним із пріоритетних напрямів соціальної політики. Так, валовий внутрішній продукт на душу населення в Україні у 2018 році становить 2,82 тис. дол. При цьому середній показник у країнах, що розвиваються, $-5,49$ тис. дол., а у світі 11,73 тис. дол. Такі результати розвитку країни є алогічними з огляду на наявний 
в Україні соціальний і трудовий потенціал. Оцінювання матеріального добробуту українського населення можливе за наявними статистичними даними та даними статистичних спостережень. Оцінювати забезпеченість населення духовними благами можна або за даними соціологічних опитувань, що вимагає спеціальних досліджень, або ж узагальнено за даними видатків державного бюджету на соціальну сферу.

Питання забезпечення добробуту населення та подолання бідності у будь-якій країні належать до пріоритетних сфер соціальної політики. Саме позитивна динаміка його показників визначає успішність соціально-економічного розвитку країни та ефективність діяльності уряду. Україна після здобуття незалежності зіштовхнулася з проблемами недофінансування соціальної сфери, зниження доходів у більшості населення та поширення бідності, обумовлених надзвичайно глибокою та тривалою трансформаційною кризою 90-х років XX сторіччя. Лише від 2000 року почалося поступове зростання добробуту, яке перервала чергова фінансово-економічна криза (2008-2009 рр.). Нового удару добробуту населення завдала агресія Росії у 2014 році. У складних умовах втрати частини територій та економічного потенціалу і збройного конфлікту на Донбасі, в яких перебуває країна останні п’ять років, проблеми низького рівня життя в Україні загострилися. Реагуючи на ці виклики, Уряд докладав зусилля для підвищення добробуту населення. Нині є певні позитивні зрушення за цими напрямами соціальної політики - зростають обсяги фінансування соціальної сфери, збільшуються доходи населення, але в той же час проблеми низької якості соціальних послуг, бідності і малозабезпеченості залишаються.

Аналіз останніх досліджень і публікацій. Високо розвинуті країни світу мають свої «рецепти» соціальної політики, які закріпилися, як правило, у певних їі моделях. Використання «готових рецептів» у соціально-економічних умовах нашої країни ускладнено, оскільки формування соціальної політики залежить від історичної спадщини, національної ментальності, соціально-економічних здобутків, суб'єктивних характеристик представників владних структур тощо. Тому, на нашу думку, доцільно аналізувати наявні в соціальній сфері проблеми, економічні можливості їх вирішення, а також стратегічні орієнтири розвитку суспільства.

Л. Підопригора (L. Pidoprugora) у статті «Соціальна політика держави як чинник прискорення євроінтеграційних процесів» (2015р.) [1] відзначає, що Україна стратегічно зорієнтована на євроінтеграцію, тому варто за взірці брати німецьку та шведську моделі соціальної політики. На нашу думку, можна взяти до уваги інструментарій соціальної політики цих країн, але визначальним у формуванні вітчизняної моделі соціальної політики має бути соціально-економічний стан країни.

Серед останніх наукових робіт щодо питань соціальної політики та добробуту населення варто звернути увагу на монографію О. Макарової (O. Makarova) «Соціальна політика в Україні» (2015) [2], де системно проаналізовано напрями, складові, фактори та інструментарій соціальної політики. В роботі детально розглянуто такі питання: взаємозв’язок між динамікою валового внутрішнього продукту (ВВП) та зайнятості - порівняно розмір заробітної плати в Україні та інших країнах світу; проаналізовано обсяг ВВП, видатки зведеного бюджету та видатки зведеного бюджету на соціально-культурну сферу; проаналізовано податкове навантаження на доходи домогосподарств; особливості реалізації соціальної політики в Україні, зокрема житлової та освітньої політики, політики щодо внутрішньо переміщених осіб тощо. Водночас, стан добробуту населення України вимагає детальнішої оцінки, а дослідження взаємозв'язку соціальної та економічної політики - використання статистичного моделювання. 
Також останнім часом стан добробуту населення та напрями його поліпшення досліджував Д. Маховський (D. Mahnovskyi) (2017) [3], зокрема він проаналізував збільшення розміру допомоги сім'ям з дітьми, пенсійного забезпечення, прожиткового мінімуму та мінімальної заробітної плати. Можемо погодитися із науковцем щодо неефективності багатозадачності соціальної політики, але вважаємо, що вона буде ефективною у випадку забезпечення взаємозв'язку соціальної та економічної складових.

Крім наукових публікацій, присвячених стану соціальної політики в країні, розглянемо наукові напрацювання з проблематики добробуту населення в Україні.

О.О. Тимошенко (О. Tуmoshenko) (2016), оцінюючи стан добробуту населення та можливості його забезпечення в Україні, акцентує увагу на активізації працездатного населення для самозабезпечення власного добробуту. Також на підставі зарубіжного досвіду науковець робить висновки про необхідність підвищення мінімальної заробітної плати до 2-2,5 прожиткових мінімумів, зменшення частки трансфертів у заробітній платі до 0,15-0,23, зменшення частки комунальних послуг у середній заробітній платі та пенсії до 0,08-0,14. На його думку, не можна визначати або обгрунтовувати напрями підвищення добробуту населення без прив'язки до економічних можливостей. Повністю згодні зі змістом публікації, але О.О. Тимошенко не дає відповіді на запитання, як ув'язати заходи підвищення добробуту із економічними реаліями.

В.В. Дружиніна (V.V. Drujinina), A.I. Макаров (A.I. Makarov) (2016), пропонуючи підхід до оцінювання добробуту населення на місцевому рівні, ототожнюють поняття «добробут населення» із поняттям «рівень та якість життя» і розмежовують у його структурі такі складові: виробнича, доходна, економічна, демографічна, освітня та майнова. На нашу думку, такий підхід ускладнює пошук заходів та можливостей підвищення добробуту населення в Україні, а поняття «добробут населення» має цілком відчутні межі - фінансове забезпечення матеріальних і духовних потреб як людини, так і населення в країні.

C.A. Дражниця (S.A. Drazhnyсуа) (2013), досліджуючи проблеми добробуту населення України та шляхи їх вирішення, приділяє увагу тлумаченню поняття «добробут населення» та його складових. Він вважає добробут населення індикатором якості життя як окремих індивідів, так і держави в цілому, а фінансове забезпечення матеріальних потреб - економічним добробутом. Також результатом досліджень науковця є виокремлення трьох напрямів, за якими виміряно добробут населення, а саме: вимірювання суспільного добробуту (обсяг ВВП, індикатори нерівності розподілу доходів), вимірювання якості розвитку (індикатори людського та соціального капіталу), вимірювання рівня та якості життя (індикатори доступності благ та забезпеченості ними індивідів). Підтримуючи його позицію щодо необхідності оцінювання добробуту населення на державному й індивідуальному рівнях, маємо вказати на відсутність конкретизованих індикаторів добробуту населення на різних рівнях. Отже, за результатами аналізу останніх публікацій, присвячених соціальній політиці та добробуту населення в Україні, можна виявити найактуальніші проблеми дослідження, зокрема розгляд головних індикаторів добробуту населення як на державному рівні, так і на рівні окремого індивіда, проблем їх точного визначення, а також установлення залежностей або можливостей зв’ язку між добробутом населення та економічними реаліями.

Новизна роботи. Уперше визначено особливості аналізу добробуту населення в Україні, серед яких неповнота статистичних даних і даних обстеження домогоспо- 
дарств, можливість населення робити заощадження та обсяги роздрібного товарообігу як об’єктивні критерії добробуту населення.

Уперше для оцінювання успішності взаємозв'язку соціальної та економічної політики запропоновано причинно-наслідкову модель, яка охоплює: ВВП на душу населення, рівень зайнятості населення, доходність від зайнятості населення, відношення ВВП до факторних доходів, відношення податкових надходжень до державного бюджету, частка видатків на соціальну сферу у податкових надходженнях, відношення державного бюджету до соціальних видатків.

Мета статті. Метою статті є розгляд та оцінювання стану добробуту населення в Україні на рівні держави і на рівні окремого індивіда, оцінювання не тільки «упущень» держави у цій сфері, але й ії здобутків, приділення уваги кількісним пропорціям взаємозв'язку соціальної та економічної політики в країні та визначення головних векторів соціальної політики у сфері підвищення добробуту населення. На нашу думку, така постановка мети відрізняється від попередніх спроб розробки соціальної політики, які були зорієнтовані на охоплення всіх їі напрямів без глибинного аналізу наявних у них проблем. Кожний із напрямів соціальної політики, на нашу думку, потребує фахового підходу. Саме тому в статті ми надаємо тільки оцінку стану добробуту населення за головними його індикаторами, а також пропонуємо причинно-наслідкову модель взаємозв’язку ВВП на душу населення з певними соціально-економічними індикаторами.

Об'єкт досліджень - добробут населення в Україні.

Методи досліджень. Для аналізу добробуту використано загальнонаукові методи дослідження (аналіз, синтез, дедукція, індукція тощо), спостереження, а також статистичного аналізу та моделювання (індексно-факторний метод).

Логіка виконаного дослідження така: 1) проаналізовано рівень життя населення у 2014-2018 рр.; 2) визначено особливості аналізу добробуту населення в Україні; 3) дано узагальнену оцінку нинішньої соціально-економічної політики України в контексті забезпечення добробуту населення. У результаті оцінювання стану добробуту населення запропоновано пріоритетні напрями цієї політики.

Виклад основного матеріалу дослідження. Для оцінки рівня життя населення України проаналізовано вартісні показники доходів і витрат населення, рівня матеріального забезпечення а також можливостей задоволення різноманітних потреб (табл. 1).

Різке падіння рівня життя населення України відбулося у 2014 році внаслідок збройного конфлікту, розв'язаного РФ, та обумовленого ним економічного спаду. Воно поглибилося у 2015 році, про що свідчить негативна динаміка індексу реальних доходів населення (складав 70,5 \% від рівня 2013 р.), реальної заробітної плати (74,6 \% від рівня 2013 р.), а також частки населення з доходами нижче за фактичний прожитковий мінімум, яка зросла майже до $52 \%$.

Поступовий вихід із глибокої прірви падіння добробуту населення почався у 2016 році завдяки динамічному зростанню заробітної плати - у 2,5 рази. Розрахунки показують, що рівень реальної заробітної плати (у цінах 2013 р.) в 2018 р. перевищив докризовий рівень і становив $109 \%$ рівня 2013 р. У той же час у сфері оплати праці залишилося багато невирішених проблем, які знижують рівень життя працюючого населення. Серед них найгострішими є: 1) зростання заборгованості невиплаченої своєчасно заробітної плати - на початок 2015 р. заборгованість складала 1320,1 млн грн, на початок 2019 р. - 2645,1 млн грн [4], зросла удвічі. I хоч їі частка у фонді оплати праці була не дуже високою - 3,4 \%, для багатьох працівників невиплачена заробітна плата залишає їх без засобів існування; 2) наявність значних груп працівників, 
Таблиия 1. Динаміка основних показників життя матеріального добробуту населення в Україні у 2014-2018 pp.

\begin{tabular}{|l|c|c|c|c|c|c|}
\hline \multicolumn{1}{|c|}{ Показник } & $\mathbf{2 0 1 4}$ & $\mathbf{2 0 1 5}$ & $\mathbf{2 0 1 6}$ & $\mathbf{2 0 1 7}$ & $\mathbf{2 0 1 8}$ & $\begin{array}{c}\mathbf{2 0 1 7 ( 1 8 ) / ~} \\
\mathbf{2 0 1 4 , \%}\end{array}$ \\
\hline $\begin{array}{l}\text { Наявні доходи на 1 особу, } \\
\text { грн / рік }\end{array}$ & 26782 & 318093 & 37080 & 45763 & - & 170,8 \\
\hline $\begin{array}{l}\text { Індекс реальних наявних } \\
\text { доходів, \% до попереднього } \\
\text { року }\end{array}$ & 88,51 & 79,61 & 102,01 & 107,4 & - & $\mathrm{X}$ \\
\hline Витрати на 1 особу, грн / рік & 34557 & 40464 & 47776 & 61102 & - & 176,8 \\
\hline $\begin{array}{l}\text { Середньомісячна заробітна } \\
\text { плата, грн }\end{array}$ & 3480 & 4195 & 5183 & 7104 & 8865 & 254,7 \\
\hline $\begin{array}{l}\text { Індекс реальної заробітної } \\
\text { плати, \% до попереднього } \\
\text { року }\end{array}$ & 93,5 & 79,8 & 109,0 & 119,1 & 112,5 & $\mathrm{X}$ \\
\hline $\begin{array}{l}\text { Середній розмір пенсії, грн } \\
\text { на 31 грудня відповідного } \\
\text { року }\end{array}$ & 1581,5 & 1699,5 & 1828,3 & 2479,2 & 2648 & 167,4 \\
\hline $\begin{array}{l}\text { Частка населення з серед- } \\
\text { ньодушовими доходами } \\
\text { нижче ПМф, \% }\end{array}$ & 16,7 & 51,9 & 51,1 & 34,9 & $29,3 *$ & $\mathrm{X}$ \\
\hline $\begin{array}{l}\text { Частка витрат домогос- } \\
\text { подарств на продтовари у } \\
\text { сукупних витратах, \% }\end{array}$ & 57,1 & 57,9 & 54,3 & 52,7 & $48,0^{*}$ & $\mathrm{X}$ \\
\hline
\end{tabular}

Джерело: складено авторами за даними Державної служби статистики України; прочерк - дані відсутні; * за 9 місяців 2018 р.; ПМф - прожитковий мінімум фактичний.

у яких заробітна плата є низькою, а також тих, у кого вона не перевищує мінімальну заробітну плату. Так, у січні 2019 р. середня заробітна плата в економіці становила 9223 грн, що у 2,2 рази вище за рівень мінімальної заробітної плати (Мін. ЗП 4173 грн), однак в освіті вона складала 7104 грн (1,7 раз до Мін. 3П), в охороні здоров’я - 6203 грн (1,48 від Мін. ЗП) [5]. В цілому в економіці близько $6 \%$ працюючих отримували заробітну плату в межах мінімального рівня.

Зростали також і пенсії, однак менше за заробітну плату. За 2014-2018 р. середній розмір пенсії збільшився у 1,7 раза. При цьому погіршилося співвідношення між середньою пенсією та заробітною платою: у 2014 р. розмір пенсії складав 45 \% від середньої заробітної палати, у 2018 р. - знизився до 30 \%. Отже, відносно зайнятих, позитивні зрушення у рівні життя пенсіонерів були значно меншими, що сприяло поширенню відносної бідності. Тому проблема бідності була найгострішою саме для осіб пенсійного віку, яких нараховувалося понад 11 млн осіб. Саме на їі вирішення була спрямована в останній період пріоритетна увага Уряду, що проявилося у індексації пенсій. За даними Пенсійного фонду України (ПФУ), на 1 березня 2019 р. середній розмір пенсії за віком складав 3158 грн, iї отримувало 8637,5 тис. пенсіонерів. Але у більшої їх частки пенсія не перевищувала 3000 тис. грн, тому подальше підвищення пенсій є актуальним завданням.

Хоч реальні наявні доходи населення і не відновилися до рівня 2013 р., певне зростання добробуту у 2016-2017 рр. відбулося, про що свідчить суттєве зниження 
частки населення з доходами нижче за прожитковий мінімум - $352 \%$ у 2015 р. до $35 \%$ у 2017 р. і до 29 \% в I-III кв. 2018 року.

Важливим показником оцінки рівня життя є частка витрат домогосподарств, які спрямовуються на продовольчі товари. Чим вищою є ця частка, тим біднішим вважається населення. В країнах Європейського Союзу частка витрат на харчування коливається в межах 15-25 \%. Дані табл. 1 свідчать, що в Україні у 2014 р. витрати на продукти харчування перевищили 57 \% усіх сукупних витрат, що вказує на низький життєвий рівень населення. У 2015 р. цей показник зріс, після чого почав знижуватися і за дев’ять місяців 2018 р. становив 48 \%. Це ще раз підтверджує, що відбувається хоч і повільне, але неухильне підвищення добробуту.

Зроблений вище аналіз засвідчує роботу органів влади, спрямовану на підвищення життєвого рівня. В той же час частка населення з доходами нижче за фактичний прожитковий мінімум, який розраховує Міністерство соціальної політики, залишається високою, що засвідчує наявність значної проблеми бідності. Це обумовлено багатьма причинами, у першу чергу - низьким рівнем економічного розвитку, підсумковим показником якого є динаміка ВВП (табл. 2).

За досліджуваний період у поточних цінах ВВП на душу населення зріс у 1,9 раза, у цінах попереднього року - в 1,8, однак з урахуванням інфляції за весь період (кумулятивний індекс споживчих цін за досліджуваний період склав 1,85 ) його обсяг у 2017 р. лише на $3 \%$ перевищив рівень 2014 р. За паритетом купівельної спроможності спостерігається падіння ВВП і лише у 2017 р. мало місце невелике зростання. Отже, можна зробити висновок про те, що у 2014-2016 роках Україна не мала економічних можливостей для зростання доходів населення, вони з'явилися лише у 2017 та у 2018 роках.

Аналізуючи проблему рівня життя та бідності в Україні, потрібно зробити декілька зауважень, які обгрунтовують неоднозначність процесів і висновків щодо матеріального становища населення України:

1. Статистичні дані і обстеження домогосподарств не надають повної інформації про доходи населення. Основними джерелами доходів домогосподарств є заробітна плата та інші трудові доходи, підприємницький дохід і пенсії. Найповнішою інформація є щодо пенсій, які офіційно виплачуються із пенсійного фонду держави.

Таблиия 2. Динаміка валового внутрішнього продукту у 2014-2018 pp.

\begin{tabular}{|l|c|c|c|c|c|}
\hline \multicolumn{1}{|c|}{ Показник } & $\mathbf{2 0 1 4}$ & $\mathbf{2 0 1 5}$ & $\mathbf{2 0 1 6}$ & $\mathbf{2 0 1 7}$ & $\begin{array}{c}\mathbf{2 0 1 7} \text { до } \\
\mathbf{2 0 1 4 ,} \%\end{array}$ \\
\hline $\begin{array}{l}\text { Валовий внутрішній продукт на 1 особу, } \\
\text { грн у фактичних цінах }\end{array}$ & 36904 & 46413 & 55899 & 70210 & 190,3 \\
\hline $\begin{array}{l}\text { Індекс споживчих цін, \% до попере- } \\
\text { днього року }\end{array}$ & 112,1 & 148,7 & 113,9 & 114,4 & $\mathrm{X}$ \\
\hline $\begin{array}{l}\text { Кумулятивний індекс споживчих цін, } \\
\text { раз відносно 2014 року }\end{array}$ & 1 & 1,487 & 1,656 & 1,846 & $\mathrm{X}$ \\
\hline $\begin{array}{l}\text { Валовий внутрішній продукт на 1 особу, } \\
\text { грн у цінах 2014 року }\end{array}$ & 36904 & 31212 & 33755 & 38043 & 103,1 \\
\hline $\begin{array}{l}\text { ВВП у розрахунку на 1 особу, тис дол } \\
\text { США, за ПКС 2010 року }\end{array}$ & 17,3 & 16,6 & 15,5 & 15,9 & 91,9 \\
\hline
\end{tabular}

Джерело: розраховано та складено авторами за даними Державної служби статистики України. 
Статистика заробітної плати, яка надається підприємствами й установами, охоплює лише частину зайнятих, оскільки у 2017 р. на підприємствах працювало 9,1 млн осіб із 16,2 млн зайнятих [6]. Значна кількість українців працюють у неформальному секторі економіки (3,7 млн осіб), їхні трудові доходи не обліковують державні статистичні органи. Щорічні обстеження домогосподарств (у 2017 р. було обстежено 7958 господарств) [7] також не висвітлюють усіх доходів, оскільки: не охоплюють найбільш заможні верстви населення; значна частка відібраних для обстеження домогосподарств відмовляється від участі у проекті (у 2017 р. їх було 17,8 \%); населення в ході обстежень не надає повної інформації про доходи.

2. Статистика доходів населення не враховує наявність значних тіньових доходів. За даними Міністерства економічного розвитку, рівень тіньової економіки у січні-вересні 2018 року склав 32 \% від обсягу офіційного ВВП, а в попередні роки був ще вищим. Отже, наявні доходи населення фактично мінімум на 1/3 були вищими від оприлюднених даних. Про значні тіньові доходи населення свідчить розбіжність між доходами та витратами домогосподарств, у 2017 р. витрати перевищували доходи на $33 \%$. Тому можна дійти висновку, що фактичне падіння життєвого рівня було дещо меншим, ніж це випливає зі статистичних даних.

3. Одним із об’єктивних критеріїв добробуту є можливість робити заощадження. Динаміка заощаджень на депозитах домашніх господарств мала різновекторну спрямованість, однак при цьому не відбулося суттєвого зменшення їх розміру. У 2014 р. на депозитах зберігалося 418133 млн грн заощаджень, їхній обсяг дещо зменшився у 2015 р. (410 895 млн), однак потім зростав і в 2017 р. склав 495313 млн грн [8], тобто зріс на 18,5 \%, при цьому зростали як гривневі, так і валютні депозити. Отже, частка населення, незважаючи на зниження рівня життя, мала змогу заощаджувати, однак темпи зростання депозитних вкладів були нижчими за темпи зростання номінальних доходів. При цьому внаслідок інфляції відбулося часткове знецінення заощаджень, що негативно позначилось на можливостях підвищення добробуту.

4. Про позитивні зрушення в добробуті населення за останні три роки свідчить також зростання роздрібного товарообігу та попиту на послуги. Якщо у порівняльних цінах товарообіг у 2014 і 2015 рр. знизився відповідно на $10 \%$ та $20 \%$, то починаючи з 2016 до 2018 року зріс на $16 \%$. Про певне зростання добробуту також свідчить динамічне зростання попиту на туристичні послуги. Якщо у 2015 р. виїздили за кордон 23,2 млн українців, то у 2018 р. - 27,8 млн, на $20 \%$ більше. В тому числі не до сусідніх країн, а до країн переважно культурного та рекреаційного туризму (Італії, Туреччини, Єгипту тощо) кількість туристичних поїздок зросла з 2,1 до 4,3 млн, більш ніж удвічі. У Туреччині в 2018 р. побувало 1,19 млн осіб, у Єгипті - 1,13 млн, у Німеччині - 0,53 млн [9].

Вирішення проблеми підвищення добробуту населення та подолання бідності є одним із ключових завдань держави. Відповідно до Цілей сталого розвитку (20152030), схвалених на саміті ООН у вересні 2015 року, розв'язання проблем подолання бідності та зменшення нерівності, підвищення рівня життя в Україні у 2016 році було затверджено Стратегію подолання бідності [10] та відповідні програми на 2016-2017 i 2018 pр. Рахункова палата України у 2018 році детально проаналізувала виконання заходів з реалізації Стратегії, та виявила здобутки і значні недоліки в діяльності усіх державних інституцій щодо виконання запланованих заходів, однак дійшла висновку, що 2017 рік став переломним у ситуації з бідністю в Україні. Вперше з 2013 року вдалося досягти зниження масштабів бідності. Про це насамперед свідчить зменшення рівня абсолютної бідності. Водночас підвищення рівня відносної бідності вказує, що 
бідніші верстви мали менший зиск від результатів економічного зростання порівняно з рештою населення [11]. Це стосується таких верств населення як: непрацюючі пенсіонери; родини з дітьми, особливо ті, в яких троє і більше дітей; соціально уразливі члени суспільства (інваліди, особи з низьким рівнем кваліфікації тощо); безробітні; в останні роки - внутрішньо переміщені особи.

Механізм формування та реалізації соціальної політики тісно пов'язаний 3 економічною складовою, формуванням та перерозподілом національного доходу і ВВП. Чим більшим є ВВП країни, тим більшими є можливості для фінансування соціального розвитку та забезпечення соціальних потреб населення. Пропонуємо для оцінювання успішності взаємозв’язку соціальної та економічної політики України використати таку причинно-наслідкову модель:

$$
\frac{\mathrm{BB \Pi}}{\mathrm{\Psi}_{\mathrm{H}}}=\frac{\mathrm{\Psi}_{3}}{\mathrm{\Psi}_{\mathrm{H}}} \times \frac{Д}{\mathrm{\Psi}_{3}} \times \frac{\text { ВВП }}{\text { Д }} \times \frac{\mathrm{B}_{\mathrm{cc}}}{\Pi \mathrm{H}} \times \frac{\Pi \mathrm{H}}{Д Б} \times \frac{\text { ДБ }}{\mathrm{B}_{\mathrm{cc}}},
$$

де: ВВП - валовий внутрішній продукт; Чн - чисельність постійного населення; $Ч_{з}$ - чисельність зайнятого населення (за методологією МОП); Д - доходи від економічної діяльності, тобто обсяги оплати праці та прибутку (змішаного доходу), за даними національних рахунків; $\mathrm{B}_{\text {сc }}$ - видатки на соціальну сферу (охорона природного середовища, ЖКГ, охорона здоров’я, духовний та фізичний розвиток, освіта, соціальний захист і соціальне забезпечення); ПН - податкові надходження; ДБ - зведений державний бюджет.

Логіка запропонованої моделі оцінки. Стан розвитку економіки країни у міжнародних розрахунках прийнято вимірювати обсягом ВВП на душу населення, який є показником ефективності соціально-економічної політики. Збільшення ВВП забезпечує зростання сукупного попиту і створює підгрунтя для економічного зростання.

На його величину впливає рівень зайнятості населення, що відображається по-

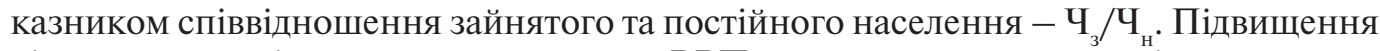
рівня зайнятості сприятиме зростанню ВВП на душу населення, оскільки зайняте населення, по-перше, створює товари та надає послуги, які задовольняють особисті та суспільні потреби в них; по-друге, є головним суб’єктом формування платоспроможного попиту на товари і послуги в економіці країни; по-третє, є платником податків до Державного бюджету та обов'язкових внесків у Фонди соціального страхування.

Наступна складова відображає доходність від зайнятості в усіх видах економічної діяльності - Д/Ч , які по суті $є$ факторними доходами. Зростання доходів від економічної діяльності на кожного зайнятого свідчить про підвищення ефективності економічної та соціальної політики.

Показник співвідношення ВВП до доходів від економічної діяльності (факторних доходів) - ВВП/Д - характеризує перевищення ВВП над факторними доходами, що свідчить про перерозподіл частини ВВП через систему непрямих податків. 3 одного боку, непрямі податки складають вагому частину державного бюджету і можуть бути використані на соціальні та інші потреби, тобто формувати частину сукупного попиту. 3 іншого, - це додатковий податковий тягар на бізнес і населення, що може гальмувати економічну діяльність.

Соціальний розвиток країни, відповідний соціальний захист та забезпечення населення країни значною мірою залежить від податкових надходжень до бюджету країни, визначених встановленими в країні ставками податків та «дисципліною» іх сплати, обсягом «тіньової економіки». Тому показник співвідношення податкових 
надходжень до держсавного бюджету (ПН/ДБ) за визначених ставок податків характеризує ефективність урядування, спроможність держави акумулювати доходи для виконання своїх функцій, зокрема і в сфері забезпечення соціального розвитку. Зниження податкових надходжень до бюджету обумовлює зростання потреби зовнішніх і внутрішніх державних запозичень та скорочення державних видатків.

Традиційно напрямами видатків державного бюджету для соціального розвитку країни є охорона навколишнього середовища, житлово-комунальне господарство, охорона здоров'я, освіта, духовний і фізичний розвиток, соціальний захист та забезпечення. Належне фінансування цих соціальних сфер формує гідний рівень життя населення. Тому показники частки видатків на соціальні сферу у податкових надходженнях (ВСС/ПН), а також співвідношення державного бюджету до соціальних видатків (ДБ/Всс) можна розглядати як індикатори соціальної орієнтації розвитку країни.

У табл. 3 наведено статистичні дані обраних для аналізу показників, які свідчать, що в поточних цінах ВВП зростав найбільш динамічно у 2017 році. При цьому зменшення чисельності зайнятих було більш динамічним, ніж зменшення всього населення, що гальмувало темп зростання. Динаміка ВВП та видатків на соціальну сферу була майже однаковою, однак спостерігається повільне підвищення частки соціальних видатків відносно ВВП: у 2014 р. вона складала 20,82 \%, у 2016 р. $21,13 \%$. Невисокий їх рівень обумовлений тим, що в Україні рівень централізації ВВП через державний бюджет є значно нижчим, ніж у країнах ЄС. Доходи від економічної діяльності зросли менше ніж ВВП - на 6 в. п. Відбулося динамічніше зростання державного бюджету і податкових надходжень, що вказує на підвищення рівня перерозподілу національного доходу через фіскальну і бюджетну систему. Обсяги податкових надходжень зросли у 2,25 раза, що перевищило темп зростання ВВП.

Таблиця 3. Динаміка показників соціально-економічного розвитку України за 2014-2017 pp.

\begin{tabular}{|l|c|c|c|c|c|c|}
\hline \multicolumn{1}{|c|}{ Показник } & \multicolumn{2}{c}{ Pік } & \multicolumn{3}{c|}{ Індекс } \\
\cline { 2 - 7 } & $\mathbf{2 0 1 4}$ & $\mathbf{2 0 1 5}$ & $\mathbf{2 0 1 6}$ & $\mathbf{2 0 1 7}$ & $\begin{array}{c}\mathbf{2 0 1 6 /} \\
\mathbf{2 0 1 4}\end{array}$ & $\begin{array}{c}\mathbf{2 0 1 7} \\
\mathbf{2 0 1 4}\end{array}$ \\
\hline $\begin{array}{l}\text { Валовий внутрішній про- } \\
\text { дукт, млрд грн }\end{array}$ & 1586,9 & 1988,5 & 2385,4 & 2982,9 & 1,5 & 1,88 \\
\hline $\begin{array}{l}\text { Чисельність постійного } \\
\text { населення, осіб }\end{array}$ & 42759661 & 42590879 & 42414905 & 42216766 & 0,991 & 0,987 \\
\hline $\begin{array}{l}\text { Чисельність зайнятого } \\
\text { населення, осіб }\end{array}$ & 18073300 & 16443200 & 16276900 & 16156400 & 0,9 & 0,893 \\
\hline $\begin{array}{l}\text { Доходи від економічної } \\
\text { діяльності (заробітна пла- } \\
\text { та та прибуток), млн грн }\end{array}$ & 1382189,9 & 1672328,5 & 2015663,0 & 2516610 & 1,458 & 1,821 \\
\hline $\begin{array}{l}\text { Розмір Зведеного держав- } \\
\text { ного бюджету, млн грн }\end{array}$ & 456067,3 & 652031,0 & 782859,5 & 1016969,5 & 1,716 & 2,230 \\
\hline $\begin{array}{l}\text { Обсяги податкових над- } \\
\text { ходжень, млн грн }\end{array}$ & 367511,9 & 507635,9 & 650781,7 & 828158,8 & 1,77 & 2,25 \\
\hline $\begin{array}{l}\text { Видатки на соціальну } \\
\text { сферу, млн грн }\end{array}$ & 330412,2 & 398992,1 & 503967,9 & 624949 & 1,525 & 1,891 \\
\hline
\end{tabular}

Джерело: складено авторами за даними Державної служби статистики України. 
Таблиия 4. Динаміка показників формування та реалізації соціальної політики в Україні у 2014-2016 pp.

\begin{tabular}{|l|c|c|c|c|c|c|}
\hline \multirow{2}{*}{ Показник } & \multicolumn{4}{|c|}{ Рік } & \multicolumn{2}{c|}{ Індекс } \\
\cline { 2 - 7 } & $\mathbf{2 0 1 3}$ & $\mathbf{2 0 1 4}$ & $\mathbf{2 0 1 6}$ & $\mathbf{2 0 1 7}$ & $\mathbf{2 0 1 7 / 2 0 1 3}$ & $\mathbf{2 0 1 7 / 2 0 1 4}$ \\
\hline ВВП/Чн, грн & 33651,67 & 37112,08 & 56239,66 & 70656,76 & 2,09 & 1,9 \\
\hline Чз/Чн & 45,09 & 42,26 & 38,37 & 38,27 & 0,85 & 0,905 \\
\hline Д/Чз & 65147,66 & 76476,89 & 123835,8 & 155765,5 & 2,39 & 2,04 \\
\hline ВВП/Д & 1,145 & 1,148 & 1,183 & 1,185 & 1,03 & 1,03 \\
\hline ПН/ДБ & 0,799 & 0,806 & 0,814 & 0,814 & 1,02 & 1,01 \\
\hline Всс/ПН & 0,959 & 0,899 & 0,754 & 0,755 & 0,79 & 0,84 \\
\hline ДБ/ Всс & 1,305 & 1,38 & 1,627 & 1,627 & 1,24 & 1,18 \\
\hline
\end{tabular}

Джерело: розраховано авторами.

Це обумовлено як збільшенням ставок податків, так і введенням нових податкових платежів, що забезпечило майже аналогічне зростання зведеного державного бюджету держави.

У табл. 4 представлені розраховані показники для запропонованої моделі оцінки соціально-економічної політики. Ці індекси показують, що зростання ВВП на душу населення забезпечено переважно за рахунок зростання віддачі від економічної діяльності на кожного зайнятого, враховуючи найманих працівників, самозайнятих і роботодавців.

На основі аналізу динаміки розрахованих показників можна зробити такі висновки щодо економічної та соціальної політики.

1. Незважаючи на складну економічну і політичну ситуацію в країні, тривалий збройний конфлікт на Сході, вдалося забезпечити зростання номінального ВВП на душу населення в поточних цінах у 2017 році відносно 2013 р. більш ніж удвічі. У 2017 р. цей показник зростав і в порівняльних цінах, що є економічною основою підвищення добробуту.

2. Забезпечено більш динамічне зростання факторних доходів на одного зайнятого в економіці, що вказує як на розширення можливостей для зростання рівня життя за рахунок економічної діяльності, так і на певне підвищення ефективності економіки.

3. Позитивна динаміка співвідношення ПН/ДБ показує, що в структурі державного бюджету повільно зростала частка податкових надходжень, що може свідчити про ефективніше адміністрування податків, певне звуження тіньового сектору економіки та зменшення залежності державних фінансів від зовнішніх запозичень. Усе це позитивно впливає на можливості фінансування соціального розвитку.

4. Динаміка показника співвідношення соціальних видатків до податкових надходжень (B сс ПН) показує зниження соціальної орієнтації податків: у 2014 р. 90 \% податків спрямовувалася на соціальні потреби, а у 2017 - 75 \%. Це обумовлено необхідністю фінансового забезпечення інших сфер державного управління, передусім оборони країни, модернізації інфраструктури, інвестицій в економіку.

5. Показник співвідношення державного бюджету до соціальних видатків (ДБ/В ${ }_{\text {cс }}$ зростав, що також вказує на зменшення соціальної складової у бюджетних витратах: у 2014 р. - на соціальні потреби направлено 72 \% зведеного бюджету, у 
2017 - 61 \%. Однак при цьому соціальні видатки держави на душу населення зростали: у 2014 році вони становили 7727 грн, у 2017 - 14803 грн, тобто підвищилися майже удвічі. В той же час в умовах наявності значних невирішених соціальних проблем цих коштів недостатньо для забезпечення суттєвих зрушень у добробуті населення.

Можна зробити висновок, що в силу об’єктивних причин (зростання витрат на оборону країни) відбулося певне зниження соціальної орієнтації державного бюджету. Водночас соціальне навантаження на бюджет в Україні є значним. Як відзначають фахівці, в структурі державних видатків країн світу соціальні видатки становлять понад 50 \% [12]. В Україні вони значно перевищують цей рівень, тому зростання добробуту населення має досягатися не за рахунок збільшення частки соціальних видатків, а за рахунок економічного зростання і більшого наповнення державного бюджету податковими платежами фізичних і юридичних осіб.

Висновки. На основі виконаного дослідження можна дійти висновку, що хоч у сфері підвищення добробуту і відбулись позитивні зміни, завдання подолання бідності та малозабезпеченості населення має залишатися одним із основних пріоритетів соціальної політики держави. Навіть із урахуванням тіньової складової, Україна значно відстає від більшості європейських країн за рівнем оплати праці та пенсійного забезпечення. Тому підвищення добробуту населення та його наближення до європейських стандартів є найважливішим завданням держави, що відповідає Цілям сталого розвитку. Реалізація цих завдань потребує зусиль у таких напрямах: забезпечення високих темпів економічного зростання; розширення можливостей зайнятості і гідної праці; забезпечення своєчасної виплати заробітної плати; підвищення рівня кваліфікації вітчизняних працівників; забезпечення масштабної детінізації економіки; формування ефективної системи перерозподілу національного доходу; забезпечення динамічнішого зростання доходів пенсіонерів, поширення дії такої соціальної гарантії як мінімальна заробітна плата на певні категорії населення поза наймом.

Перспективи подальших досліджень. Виходячи з гостроти проблеми добробуту в Україні та ії соціальної значущості, перспективи подальших досліджень у цій сфері, на нашу думку, мають стосуватися таких аспектів: підвищення повноти й достовірності інформації щодо оцінки рівня життя різних верств населення України, оскільки на сучасному етапі така оцінка $є$ певною мірою викривленою внаслідок значної тінізації економіки та приховування доходів; оцінки впливу темпів економічного зростання на параметри добробуту зайнятого і незайнятого населення, передусім пенсіонерів, рівень життя яких суттєво погіршується після припинення трудової діяльності, розробка механізмів забезпечення рівномірніших зисків від економічного зростання для усіх верств населення; визначення умов та шляхів підвищення рівня економічної активності і зайнятості населення, забезпечення гідної оплати праці як економічної основи зростання добробуту. Поглиблення досліджень у цих напрямах сприятиме розробці ефективнішої соціальної політики у сфері добробуту.

\section{ЛІТЕРАТУРА}

1. Підопригора Л.А. Соціальна олітика держави як чинник прискорення євроінтеграційних процесів // Науковий часопис НПУ імені МП Драгоманова. Серія 18: Економіка і право. 2015. - № 27. - С. 41-48.

2. Макарова О.В. Соціальна політика в Україні / Ін-т демографії та соціальних досліджень ім. М.В. Птухи НАН України. - Київ, 2015. - 244 с. 
3. Маховський Д. Соціальна політика України: стан та перспективи розвитку // Економічний часопис Східноєвропейського національного університету імені Лесі Українки. - 2017. № 2. - C. 31-37.

4. Тимошенко О.О. Оцінка стану і можливостей забезпечення добробуту населення в Україні на основі стандартів розвинениї країн // Вісник Дніпровського університету. Серія «Світове господарство і міжнародні економічні відносини». - 2016. - Вип. 8. - С. 77-85.

5. Дружиніна В.В. Результативність оцінки добробуту населення на місцевому рівні // Ефективна економіка. - 2016. - № 5 [Електронний ресурс]. - Режим доступу: http://www.economy.nayka. com.ua (дата звернення: 04.03.2019).

6. Дражниия С.А. Добробут населення України: проблеми та шляхи їх вирішення // Університетські наукові записки. - 2013. - № 2 (46). - С. 303-309.

7. Заборгованість із виплати заробітної плати. Статистична інформація [Електронний ресурс]. - Режим доступу: http://www.ukrstat.gov.ua/ (дата звернення: 04.03.2019).

8. Заробітна плата у січні 2019 року. Експрес Випуск [Електронний ресурс]. - Режим доступу: http://www.ukrstat.gov.ua (дата звернення: 04.03.2019).

9. Економічна активність населення України у 2017 р. [Електронний ресурс]. - Режим доступу: http://www.ukrstat.gov.ua (дата звернення: 04.03.2019).

10. Витрати і ресурси домогосподарств України у 2017 році [Електронний ресурс]. - Режим доступу: http://www.ukrstat.gov.ua (дата звернення: 04.03.2019).

11. Статистичний щорічник України за 2017 рік [Електронний ресурс]. - Режим доступу: http://www. ukrstat.gov.ua (дата звернення: 04.03.2019).

12. Інформація щодо відвідування України іноземцями та виїзду громадян України за кордон (2015-2018 роки) [Електронний ресурс]. - Режим доступу: http://www.me.gov.ua (дата звернення: 04.03.2019).

13. Про схвалення Стратегії подолання бідності: Розпорядження Кабінету Міністрів України від 16.03.2016 № 161-p. [Електронний ресурс]. - Режим доступу: https://rada.gov.ua (дата звернення: 04.03.2019)

14. Звіт про результати аналізу виконання заходів з реалізації Стратегії подолання бідності [Електронний ресурc]. - Режим доступу: http://www.ac-rada.gov.ua (дата звернення: 04.03.2019).

15. Боярко I., Дехтяр Н., Дейнека О. Аналіз бюджетної політики країн ЄС та України у сфері формування та використання державних видатків // Вісник НБУ. - 2013. - Верес. - С. 18.

\section{REFERENCES}

1. Pidopryhora, L.A. (2015). Sotsialna polityka derzhavy yak chynnyk pryskorennia yevrointehratsiinykh protsesiv [Social policy of the state as a factor of acceleration of European integration processes]. Naukovyi chasopys Natsionalnoho pedahohichnoho universyteta imeni M.P. Drahomanova - Scientific journal of the National Pedagogical University named after M.P. Drahomanov, 27, 41-48 [in Ukrainian].

2. Makarova, O.V. (2015). Sotsialna polityka v Ukraine [Social policy in Ukraine]. Kyiv: Instytut demohrafii ta sotsialnykh doslidzhen imeni M.V. Ptukhy Natsionalnoi akademii nauk Ukrainy [in Ukrainian].

3. Makhovskyi, D. (2017). Sotsialna polityka Ukrainy: stan ta perspektyvy rozvytku [Social policy of Ukraine: the state and prospects of development]. Ekonomichnyi chasopys Skhidnoievropeiskoho natsionalnoho universytetu imeni Lesi Ukrainky - Economic Journal of Lesya Ukrainka East-European National University, 2, 31-37 [in Ukrainian].

4. Tymoshenko, O.O. (2016). Otsinka stanu i mozhlyvostei zabezpechennia dobrobutu naselennia v Ukraini na osnovi standartiv rozvynenyi krain [Assessment of the status and providing welfare opportunities of the population in Ukraine on the basis of developed countries' standards]. Visnyk Dniprovskoho univer-sytetu. Seriia «Svitove hospodarstvo i mizhnarodni ekonomichni vidnosyny»-Bulletin of the Dnipro University. Series “World Economy and International Economic Relations”, 8, 77-85 [in Ukrainian].

5. Druzhynina, V.V. (2016). Rezultatyvnist otsinky dobrobutu naselennia na mistsevomu rivni [The resultant is looking for a dobrobut to naselennia na mistsevomu rivni]. Efektyvna ekonomika - Effective economy. Retrieved from http://www.economy.nayka.com.ua [in Ukrainian].

6. Drazhnytsia, S.A. (2013) Dobrobut naselennia Ukrainy: problemy ta shliakhy yikh vyrishennia [The welfare of the Ukrainian population: the problems and ways of their solution]. Universytets'ki naukovi zapysky - University Scientific Notes, 2(46), 303-309 [in Ukrainian]. 
7. Zaborhovanist iz vyplaty zarobitnoi platy [Arrears of wages]. (n.d.). State Statistics Service. Retrieved from http://www.ukrstat.gov.ua [in Ukrainian].

8. Zarobitna plata u sichni 2019 roku [Wages in January 2019] (2019). State Statistics Service. Retrieved from http://www.ukrstat.gov.ua [in Ukrainian].

9. Ekonomichna aktyvnist naselennia Ukrainy u $2017 \mathrm{r}$. [Economic activity of the population of Ukraine in 2017]. (2018). State Statistics Service. Retrieved from http://www.ukrstat.gov.ua [in Ukrainian].

10. Vytraty i resursy domohospodarstv Ukrainy u 2017 rotsi [Costs and resources of Ukrainian households in 2017] (2018). State Statistics Service. Retrieved from http://www.ukrstat.gov.ua/ [in Ukrainian].

11. Statystychnyi shchorichnyk Ukrainy za 2017 rik [Statistical Yearbook of Ukraine for 2017] (2018). State Statistics Service. Retrieved from http://www.ukrstat.gov.ua [in Ukrainian].

12. Informatsiia shchodo vidviduvannia Ukrainy inozemtsiamy ta vyizdu hromadian Ukrainy za kordon (20151018 roky)[ Information on visiting Ukraine by foreigners and departure of Ukrainian citizens abroad (20152018)] (n.d.). Ministry of Economic Development and Trade of Ukraine. Retrieved from http://www. me.gov.ua [in Ukrainian].

13. Pro skhvalennia Stratehii podolannia bidnosti: Rozporiadzhennia Kabinetu Ministriv Ukrainy vid 16.03.2016 № 161-r [ On Approval of the Strategy for Overcoming Poverty: Order of the Cabinet of Ministers of Ukraine dated March 16, 2016 No. 161-p] (2016, 16 March). Verkhovna Rada of Ukraine. Retrieved from https://rada.gov.ua [in Ukrainian].

14. Zvit pro rezultaty analizu vykonannia zakhodiv z realizatsii Stratehii podolannia bidnosti [Report on the results of the analysis of fulfillment action of implementating the Strategy for Overcoming Poverty]. (n.d.). Accounting Chamber. Retrieved from http://www.ac-rada.gov.ua [in Ukrainian].

15. Boiarko, I., Dekhtiar, N., \& Deineka, O. (2013). Analiz biudzhetnoi polityky krain YeS ta Ukrainy u sferi formuvannia ta vykorystannia derzhavnykh vydatkiv [Analysis of fiscal policy of the countries of the European Union and Ukraine in the sphere of formation and use of state expenditures]. Visnyk natsionalnoho banku Ukrainy - Bulletin of the Ukrainian National Bank, September, 18 [in Ukrainian].

Стаття надійшла до редакції 14.05.2019. 